\title{
Antecedents of Packaging of Product and Its Effect on Customer's Perception towards the Use of Perfumes
}

\author{
SAQIB SHAHZAD \\ Demonstrator, Abdul Wali Khan University, Mardan \\ PhD Scholar, Institute of Management Sciences, Peshawar \\ saqibshahzad26@gmail.com \\ SHAHZAD KHAN \\ Assistant Professor, University of Haripur, Haripur \\ PhD-Scholar, International Islamic University, Islamabad \\ DR. SHAHID JAN \\ Associate Professor, Abdul Wali Khan University, Mardan \\ MUHAMMAD TUFAIL \\ Lecturer, Abdul Wali Khan University, Mardan
}

\begin{abstract}
The purpose of the study was to find out the antecedents of packaging of product and its impact on customer's perception towards the purchase of perfumes. 250 questionnaires were distributed using convenient sampling technique. 179 properly filled questionnaires were returned forming a response rate of $71.6 \%$. the results of the study revealed that packaging of product was found to have significant impact towards the perception of customers. The four factors of packaging i.e. color, design, material used and text and graphics used were also found to have significant impact on customer perception. Hence all the hypotheses of the study were accepted.
\end{abstract}

Keywords: Packaging, color, design, material used, text and graphics, customer perception

\section{Introduction}

The focused environment on account of bundling has changed because of the consistent self-administration and clients request. The organizations now focus on the significance of bundling because of the expanding deals which is the principle wellspring of client's fascination. The organizations are ceaselessly turning towards bundling of the items to expand their deals. Today sharp and savvy bundling works like a magnet to draw in the clients. There are numerous variables that assume a basic part in the bundling of an item, similar to the shading plan, outline, data and logo. Thus all these components have impact in alluring and enhanced bundling. Another vital thing that must be specified here is that any component or blend of more than one variable can be the alluring hotspot for clients. There are especially six elements that are to be surveyed before bundling choices 
these variables are size, shape, material, shading, content and brand, (Kotler, 2010). So these components assume a contributing part in creating discernment around an item. It is the most essential method of correspondence in showcasing. Bundling is a vital segment for the clients in purchasing choice. The unrivaled reason an association can have is to accomplish the client recognition around a particular item in line by giving appealing look to the item fit as a fiddle of bundling. At the point when the firm forms some picture in the psyche of the clients then the offers of the items increments without anyone else's input. Building that picture is a vital undertaking to accomplish in the realm of showcasing. Clients are not effortlessly pulled in towards the items particularly when purchasing costly items. In any case, that can be just done through creative and alluring bundling that can catch clients.

\subsection{Problem Statement}

The importance of packaging cannot be ignored at any stage by the manufacturing companies. There is a need to know whether which factor carries utmost importance towards the perception of customers.

\subsection{Research Questions}

- What is the effect of packaging on customer perception?

- Is there any relationship between color scheme, design, material used in packaging that attract customers?

\subsection{Objectives of the study}

- To find out the effect packaging on the customer perception.

- To investigate the effect of color schemes on the customer perception.

- To study the effect of design on customer perception.

- To examine the effect of material used in packaging on the customer perception.

- To study the effect of text and graphics on the customer perception

\section{Literature Review}

As per Patwardhan, Flora and Gupta (2010) the customer discernments examination depends on shopper's obtaining conduct. It goes for enhancing business execution through a comprehension of client's inclinations and wishes. The buyer inclines toward those items which incorporate great bundling, cost, accessibility, fixings and item notoriety. So bundling had impacted the item buy as observation in the brain of clients was constructed. Kotler (2003) said that there are six components that must be evaluated when settling on bundling choices that are (size, structure, material, shading, content and brand). The examination comes about that bundle had solid impact on client's recognition and bundling is the most vital method of correspondence in advertising. Bundling is an essential component in the client purchasing choice. Bed (2008) contemplated the bundling and marking of the items. In his study he found that $84.37 \%$ shoppers were utilizing the item by taking a gander at the marking and bundling of the specific item. Bundling and naming are imperative in the items. As per Liang (2008) bundling is a critical part of the item that is utilized for commonsense reason, as well as goes about as a method for open data of the items and brand character. Packaging provides a protection to the product which consists of the shape, design, color, labeling and material (Arens, 1996). Underwood, Klein and Burke (2001) found that packaging is utilized as a device 
for brand interchanges. They promote incorporate that bundling of an item assumes a key part in drawing in the customer's consideration regarding increase upper hand. Bundling serves like as a noteworthy specialized instrument on the accompanying subtle elements which are firstly the bundling touches the purchasers in the gathering (Olga \& Natalia, 2006). Also bundling propels the customers in acquiring and thirdly the data present on the bundling helps the buyers in purchasing. According to the study of Silayoi and Speece (2004) they found that the graphical components of packaging are the size and shape of the package. Also, as mentioned, the graphical elements include design, color combinations, font and product identifications as they play a major role in making an image for the product. They further illustrate that poor graphics can reduce the sale for companies, while eye-catching graphics can improve the sales of the company. Packaging that is the size and shape play a vital role in the usability of the products. Packaging design includes the elements of graphics and color in fruit juice packages, colors work as strength in the juice taste (Hutchings, 2003). According to Deliza, Rosenthal and Silva (2003) producers should keep in mind the consumer beliefs when designing the labels and must add the sensual characteristics of the product. Munrray and Delahunty (2000) found that the producers should try to achieve the sensual packaging characteristics if they want to be successful in satisfying the needs of the consumers. Rettie and Brewer (2000) described the importance of proper positioning of packaging and said that there are two elements: verbal and visual. Packaging elements were classified (Jurgita, Rutelione, \& Vitalija 2008) and focused on the verbal elements which are product name, brand, and information and the non-verbal are size, form color, images, graphics, and materials. They described the brand as a verbal component whereas according to Kotler (2003) the basic elements of the brand are name, logo, symbol, graphics, and slogans.

\subsection{Hypotheses of the study}

$H_{l}$. Packaging has significant effect on customer perception.

$\mathrm{H}_{2}$. Color has significant effect on customer perception.

$H_{3}$. Design has significant effect on customer perception.

$H_{4}$. Material Used has significant effect on customer perception.

$H_{5}$. Text and Graphics has significant effect on customer perception 


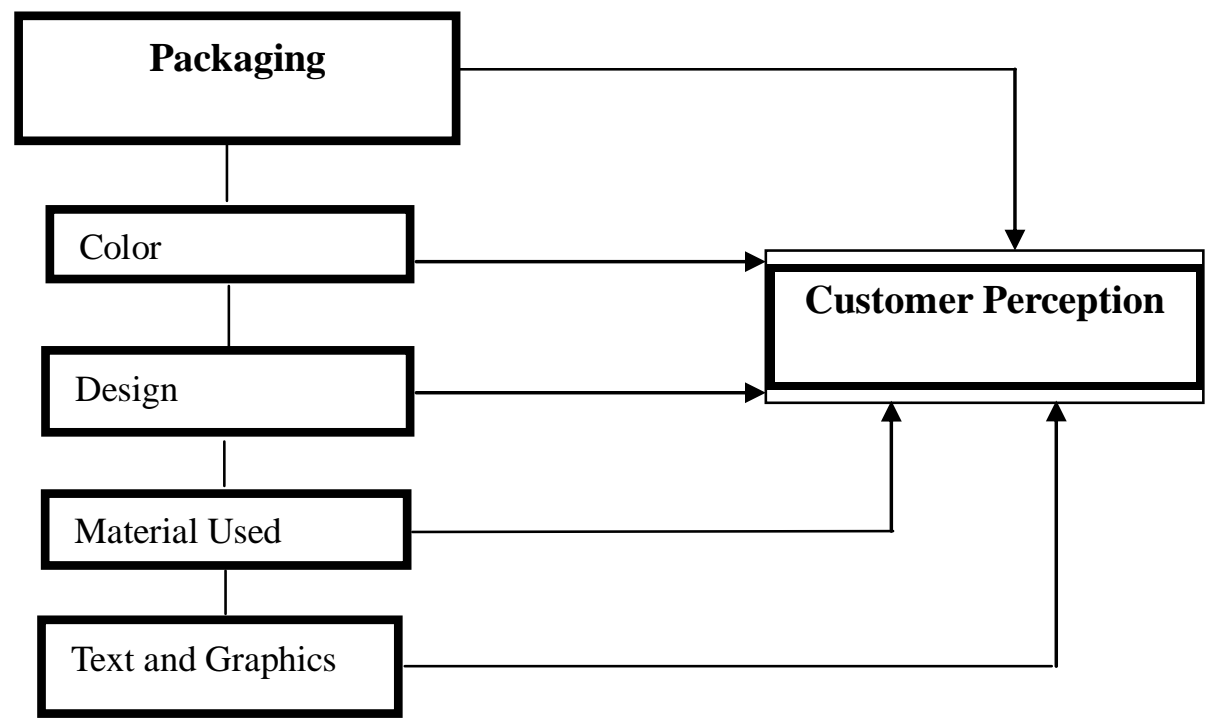

\section{Methodology}

Figure 1: Conceptual Framework

The research was explanatory in nature. The population of the study was the students enrolled in business studies, in Peshawar city. The research was conducted using the sample of respondents who are using perfume products regularly. Primary data was collected through structured questionnaire using convenient sampling technique. A sample size of 250 was selected for the study. 179 properly filled questionnaires were returned forming a response rate of $71.6 \%$ were included in the analysis. The questionnaire consists of two broad sections where section one included demographic characteristics of the respondents like gender, age currently enrolled program etc while section two comprised of items for their respective variables.

\section{Results and Findings}

Table 4.1: Gender of the Respondents

\begin{tabular}{|llcccc|}
\hline & & & & Valid & Cumulative \\
Valid & Male & 113 & 63.12 & 63.12 & 63.12 \\
& Female & 66 & 36.88 & 36.88 & 100 \\
& Total & 179 & 100 & 100 & \\
\hline
\end{tabular}

In the above table 4.1 of Gender, there were 113 male respondents having a percentage rate of $63.12 \%$ while the frequency of female respondents were 66 having a percentage rate of $36.88 \%$. 
Table 4.2: Education of the Respondents

\begin{tabular}{|llrrrr|}
\hline & & & Valid & Cumulative \\
Valid & Bachelor & 106 & 59.22 & 59.22 & 59.2 \\
& Master & 73 & 40.78 & 40.78 & 100 \\
& Total & 179 & 100 & 100 & \\
\hline
\end{tabular}

The above table 4.2 shows that 106 respondents with $59.22 \%$ were having Bachelors degree while 73 respondents with $40.78 \%$ were Master degree holders.

Table 4.3: Reliability Statistics

\begin{tabular}{|llcc|}
\hline S.No & Variable & $\begin{array}{l}\text { Cronbach's } \\
\text { Alpha }\end{array}$ & $\begin{array}{l}\text { No. } \\
\text { Items }\end{array}$ \\
\hline 1 & Color & 0.699 & 4 \\
2 & Design & 0.721 & 4 \\
3 & Material used & 0.701 & 3 \\
4 & Text and Graphics & 0.681 & 4 \\
5 & Customer Perception & 0.717 & 5 \\
\hline
\end{tabular}

The above table 4.3 of reliability statistics explain that there were 4 items for measuring color $(\alpha=0.699), 4$ items for design $(\alpha=0.721), 3$ items for measuring material used $(\alpha=0.701), 4$ items for measuring text and graphics $(\alpha=0.681)$, and 5 items for measuring customer perception $(\alpha=0.717)$. Since all the values of cronbach's alpha are greater than 0.7 except for the measure color which is also closer to 0.7 , show that the questionnaire was highly reliable.

Table 4.4: Model Summary ${ }^{\mathrm{a}}$

\begin{tabular}{|c|c|c|c|c|c|c|}
\hline \multirow[b]{2}{*}{ Model } & \multirow[b]{2}{*}{$\mathrm{R}$} & \multirow[b]{2}{*}{ R Square } & \multirow{2}{*}{$\begin{array}{c}\text { Adjusted R } \\
\text { Square }\end{array}$} & \multicolumn{3}{|c|}{ Change Statistics } \\
\hline & & & & R Square Change & F Change & Sig. F Change \\
\hline 1 & .631 & .426 & .412 & .426 & 18.421 & .000 \\
\hline
\end{tabular}

a. Predictors: (Constant), Packaging of product

In the above table 4.4 the value of adjusted $\mathrm{R}$ square is 0.412 reflects that $41.2 \%$ variation in customer perception has been explained by packaging. The value of $\mathrm{F}$ Change is 18.421 with significance level $.000(\mathrm{p}<0.05)$ which represents that model is statistically highly significant. 
Table 4.5: Coefficients ${ }^{\mathrm{a}}$

\begin{tabular}{|cc|c|c|c|}
\hline \multirow{2}{*}{} & Model & Standardized Coefficients & & \\
\cline { 2 - 3 } & Beta & $\mathrm{t}$ & Sig. \\
\hline 1 & & 3.19 & 0.002 \\
& $\begin{array}{c}\text { (Constant) } \\
\text { Packaging of } \\
\end{array}$ & & & \\
\hline
\end{tabular}

a. Dependent Variable: Customer Perception

In the above table 4.5 the Beta represents the unit(s) change in the dependent variable because of one unit change in the independent variable. The Beta value is 0.636 represents that one unit increase in packaging of product causes 0.636 units increase in creating customer perception. The $t$ value at $5 \%$ significance level is 6.135 with a significance level .000 ( $\mathrm{p}<.05)$. On the basis of the evidence mentioned above it can be said that Packaging of product has significant effect on customer perception. So the hypothesis $\mathrm{H}_{1}$ is accepted.

\section{Table 4.6: Model Summary ${ }^{\mathrm{a}}$}

\begin{tabular}{|c|c|c|c|c|c|c|c|c|c|}
\hline \multirow[b]{2}{*}{ Model } & \multirow[b]{2}{*}{$\mathrm{R}$} & \multirow[b]{2}{*}{$\begin{array}{c}\mathrm{R} \\
\text { Square }\end{array}$} & \multirow[b]{2}{*}{$\begin{array}{l}\text { Adjusted } \\
\text { R Square }\end{array}$} & \multirow[b]{2}{*}{$\begin{array}{l}\text { Std. Error } \\
\text { of the } \\
\text { Estimate }\end{array}$} & \multicolumn{5}{|c|}{ Change Statistics } \\
\hline & & & & & $\begin{array}{c}\mathrm{R} \\
\text { Square } \\
\text { Change }\end{array}$ & $\begin{array}{c}\mathrm{F} \\
\text { Change }\end{array}$ & df1 & df 2 & $\begin{array}{l}\text { Sig. F } \\
\text { Change }\end{array}$ \\
\hline 1 & .609 & .531 & .498 & .61474 & .531 & 5.131 & 1 & 94 & .002 \\
\hline
\end{tabular}

a. Predictors: (Constant), Color, Design, Material Used, Text \&Graphics

The table 4.6 of model summary reveal that the value of $\mathrm{R}=0.609$ means that there is $60.9 \%$ association among the variables of the model. The value of adjusted $\mathrm{R}$ square $=0.498$ show that $49.8 \%$ variation in customer perception is caused because of variations in the color, design, material used, text and graphics. The value of $F$ change is $5.131(\mathrm{p}=0.002)$ show that the mode is statistically significant. 
Table 4.7: Coefficients ${ }^{\mathrm{a}}$

\begin{tabular}{|c|c|c|c|c|c|}
\hline \multirow[t]{2}{*}{ Model } & \multicolumn{2}{|c|}{$\begin{array}{l}\text { Unstandardized } \\
\text { Coefficients }\end{array}$} & \multirow{2}{*}{$\begin{array}{l}\text { Standardized } \\
\text { Coefficients }\end{array}$} & \multirow[t]{2}{*}{$\mathbf{t}$} & \multirow[t]{2}{*}{ Sig. } \\
\hline & B & $\begin{array}{l}\text { Std. } \\
\text { Error }\end{array}$ & & & \\
\hline \multirow{5}{*}{$\begin{array}{l}\text { Clr } \\
\text { Dsg } \\
\text { MU }\end{array}$} & 0.617 & 0.301 & & 2.02 & 0.010 \\
\hline & 0.314 & 0.304 & 0.436 & 3.11 & 0.000 \\
\hline & 0.528 & 0.135 & 0.581 & 4.14 & 0.000 \\
\hline & 0.462 & 0.129 & 0.551 & 3.04 & 0.000 \\
\hline & 0.512 & 0.211 & 0.628 & 4.27 & 0.000 \\
\hline \multicolumn{6}{|c|}{$\begin{array}{l}\text { a. Dependent Variable: Customer Perception } \\
\text { Where, Clr=Color, Dsg=Design, MU=Material Used, TG=Text and } \\
\text { Graphics }\end{array}$} \\
\hline
\end{tabular}

The above table 4.7 of coefficients states that the $\beta$ values for Color, Design, Material Used and Text and Graphics respectively are $0.314,0.528,0.462$ and 0.512 show the respective change in the customer perception to one unit increase in color, design, material used and text and graphics. The $t$ value for color is $(t=3.105, p=.000)$, for design $(t=4.144$, $\mathrm{p}=.000)$, for material used $(\mathrm{t}=3.038, \mathrm{p}=.000)$ and for text and graphic $(\mathrm{t}=4.271, .000)$. Since all the $\mathrm{t}$ values are significant so the hypotheses $\mathrm{H}_{2}, \mathrm{H}_{3} \mathrm{H}_{4}$ and $\mathrm{H}_{5}$ are accepted respectively.

\section{Conclusion and Discussion}

The aim of the study was to find out the impact of determinants of packaging of product on customer perception. The results of the study show that packaging of item was found to have huge effect on the customer recognitions. The results of the study were in connection with the study of Klein and Burke (2001). All the components of bundling of item which are shading, plan, material utilized and content and design are essential in bundling of an item. The customer's observations with respect to the bundling of the scents are particularly positive, Silayoi and Speece (2004). It is apparent that the element shading speaks to that customers concur with the significance of shading towards bundling. The outline variable in the bundling is noteworthy which demonstrates that clients of the fragrance item are indicating significance to it. The material utilized component as a part of the bundling of the aroma item speaks to that customers of the item know about the significance of this element and are especially intrigued by the material utilized as a part of the bundling of the item. The content and design component in the bundling is likewise exceptionally huge as the clients of the scent item speak to.

\subsection{Limitations of the study}

While conducting the study the researchers faced few limitations. The first limitation was that the study was only conducted in Peshawar city, which can't serve the purpose of generalization. The second limitation was the study was focused on students this may give a very clear picture of the perfume user since people other than students were not considered in the study. The study was only conducted in students of private sector universities. 


\subsection{Recommendations and direction for further study}

Based on the results of the study the researchers' recommend that the perfume manufacturing companies need to give utmost importance to the packaging and its components. The packaging material need to be revised with frequency so that customers are more attracted towards the product as this will give a new and fresher look to the customers. In future, if such study is to be conducted then the same variables needs to be considered and the individuals other than students must be included in the sampling frame. The students of colleges need to be included in sampling frame as well. It is recommended that a comparative study may be conducted regarding gender in category of students.

\section{References}

Bed, S. (2008). New consumer products branding, packaging and labeling in Nepal. The Journal of Nepalese business studies, Vol. 5(1).

Deliza, R., Rosenthal, A., \& Silva, A., L., S. (2003). Consumer Attitude towards Information on Non-Conventional Technology. Trends in Food Science \& Technology. Vol. 14 (1/2), 43-49.

Hutchings, J., B. (2003). Expectations and the Food Industry, The impact of color and appearance. New York. Kluwer Academic Plenum Publishers.

Jurgita, S., Rutelione, A., \& Vitalija, B. (2008). Impact of Consumer Package Communication on Consumer Decision Making Process. Engineering Economics. (1), pp. 57-65.

Kotler, P. (2003) Marketing management, 9th ed. Upper Saddle River: Prentice-Hall.

Kotler, P. (2003) Marketing management, 9th ed. Upper Saddle River: Prentice-Hall.

Kotler, P. (2010) Marketing management, 13th ed. Upper Saddle River: Prentice-Hall.

Liang, L. (2008) Packaging as a strategic tool. University of Halmstad school of Business and Engineering.

Murray, J. M., \& Delahunty, C. M. (2000). Mapping consumer preference for sensory and packaging attributes of Cheddar cheese. Food Quality and Preference. (11), 419-435.

Olga, A., \& Natalia, V. (2006). Consumer Perceptions of Product Packaging. Journal of Consumer Marketing, 23/2, pp. 100-112.

Patwardhan, M., Flora, P., \& Gupta, A. (2010). Identification of Secondary Factors that Influence Consumer's Buying Behavior for Soaps and Chocolates. The Journal of Marketing Management. Vol. 9. Pp. 57-72.

Rettie, R., \& Brewer, C. (2000). The verbal and visual components of package design. Journal of Product \& Brand Management. Vol. 9 (1). 56-70.

Silayoi, P., \& Speece, M. (2004). Packaging and purchase decisions: An exploratory study on the impact of involvement level and time pressure. British Food Journal, 106 (8), 607-628

Underwood, R., L., Klein, N., M., \& Burke, R. R. (2001). Packaging communication: attention AL effects of product imagery. Journal of Product \& Brand Management. Vol. 10 (7). Pg. 403-422. 